\title{
Some Environmental Issues of Inland Valleys: A Case Study*
}

\author{
E. K. Asiam and E. Buaben
}

Asiam, E. K. and Buaben, E. (2008). "Some Environmental Issues of Inland Valleys: A Case Study", Ghana

Mining Journal, pp. 38 - 42.

\begin{abstract}
Inland valleys have complex geo-ecological systems and hence biochemical accumulation of heavy metals in soils is inevitable. Such a situation can affect crop physiology and produce quality. This study was therefore carried out to ascertain the extent of heavy metal accumulation in Anum inland valley which fringed a mining concession at Konongo in Ghana. The study revealed that accumulation of heavy metals particularly iron and lead occurred in soils and crops, a phenomenon that can result in reduction of crop quality and yield from such valleys. The concentration of lead in the rice tissue was between $2 \mathrm{mg} / \mathrm{kg}$ and $13 \mathrm{mg} / \mathrm{kg}$ while that of iron was between $1400 \mathrm{mg} / \mathrm{kg}$ and $4500 \mathrm{mg} / \mathrm{kg}$. The study concluded that inland valleys can be real environmental liability because produce from such valleys can be polluted and hence can be a source of social conflict particularly when they fringe mineral concessions as the adverse impacts could be unfortunately attributed to mining activity and similar land uses. Hence, development of a mine in such areas requires a comprehensive environmental impact assessment to ascertain the environmental quality of the adjoining inland valleys to prevent social conflict with the host community.
\end{abstract}

\section{Introduction}

Inland valleys are the upper reaches of river systems, comprising of valley bottoms and minor floodplains, which may be submerged for most part of the year. Hence inland valleys can make a major contribution to food security (Windmeijer and Andriesse, 1993).

Consequently, farmers especially those in rice and vegetable production have intensified cultivation in valleys due to their reliable water systems. This has created a highly dynamic situation as a wide variety of inland cropping systems and water management practices are emerging and the importance of valleys are gradually increasing. For example in Ghana the Anum valley is one of the numerous valleys that has been developed by the Government of Ghana into an irrigation project under the Ghana Irrigation Development Authority (GIDA) with the assistance of the Chinese Government to assist small-scale farmers to efficiently produce rice under irrigation to improve their incomes. Since runoffs and seepage drain into inland valleys the soil can be contaminated with heavy metals and micronutrients, which are applied to sustain crop yield. Contamination of soils with heavy metals affects the biochemical processes occurring in the soil. For instance, a high level of cadmium and zinc in the soil cause reduction in respiration rates and inhibits movements of air in the soil thereby impairing the activities of microorganisms in soils. This may lead to deleterious effect on plants and animals, as well as the humans eating them. Hence, there is a high probability of potentially toxic heavy metals entering the food chain (Baker and Brooks, 1989). Furthermore it has been observed in the past four years that rice yields in some fields of the Anum Valley have fallen below normal levels despite application of sufficient plant nutrients such as Nitrogen, Phosphorous and Potassium (NPK).

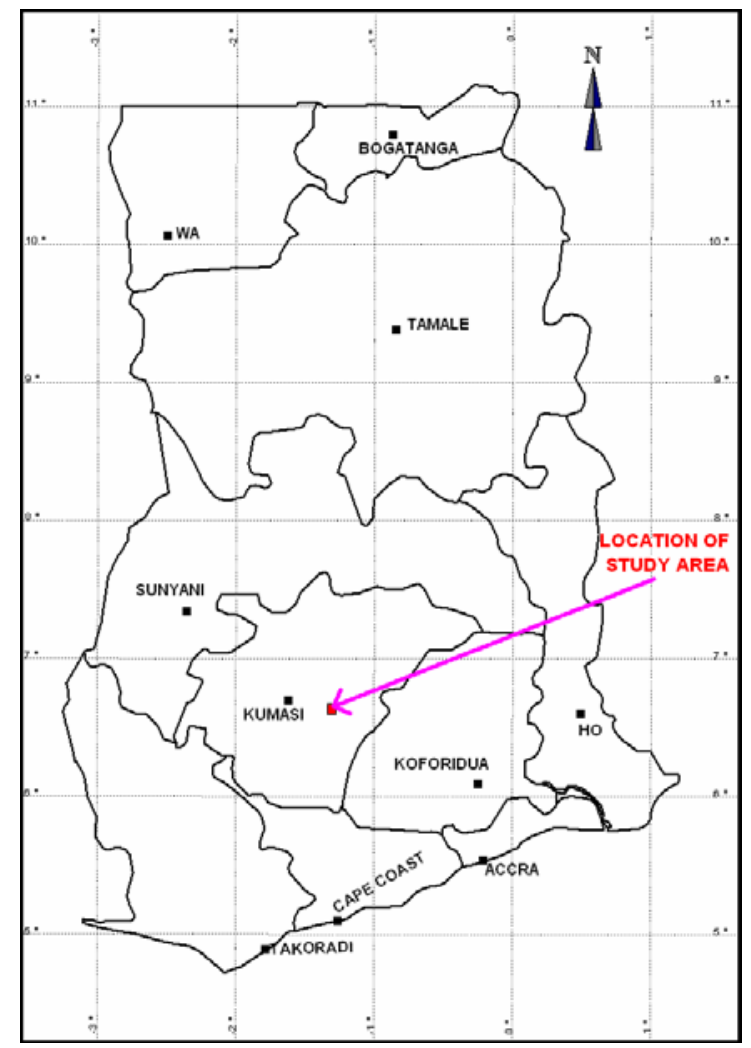

Fig. 1 Location of the Study Area

* Manuscript received January 04, 2008

Revised version accepted October 10, 2008 
Inland valleys are found in and around many mining concessions like Anum Valley near Konongo and low yield from such fields could be attributed to mining activity in the area. This situation can trigger a social conflict between mining companies and the host community.

The objective of this paper therefore is to ascertain the environmental quality of inland valley using Anum Valley as a case study to enable stakeholders manage environmental issues of such inland valleys properly.

\section{The Study Area}

The study was conducted in the Anum valley (Fig 1) irrigation project, located at about $33 \mathrm{~km}$ southeast of Kumasi in the Asante Akyem district of the Ashanti region. The Anum, Oweri, Seakyino, Anwheaso and Atotosu rivers drain the valley. The area lies approximately on Latitude $06^{\circ} .35 \varnothing$ and $06^{\circ} .54 \varnothing$ North and longitude $01^{\circ} .04$ cand $01^{\circ} .23 \varnothing$ West of the Greenwich Meridian. The Irrigation Project covers an area of about 140 ha. The area is divided into two zones $\mathrm{A}$ and $\mathrm{B}$. Within the zones are laterals and paddy fields known as plots. A plot size is about $20 \mathrm{~m}$ by $50 \mathrm{~m}$.

\section{Topography and Soil Geology}

Geologically, the area lies within the lower and upper Birimian formations. The bedrock is made up of weathered phyllite with intercalation of meta-greywackes with very variable bedrock topography. The phyllites are overlain at various levels by gravelly to pebbly sand, quartzitic gravelly silts and sands, and the silty sands are generally overlain by sandy clays and silty to sandy clays (Anon, 1991). The area is generally undulating - with a flat valley, which rises slightly at both ends.

\section{Climate}

The rainfall pattern is bimodal and average annual rainfall is $1458 \mathrm{~mm}$. The average maximum temperature is $30{ }^{\circ} \mathrm{C}$ and the average minimum temperature is $21^{\circ} \mathrm{C}$. The average daily hours of sunshine is about 5.54 hours. However, the sunshine hours differ greatly every month.

\section{Methodology}

\subsection{Sampling and Analysis}

\subsubsection{Soil}

Soil samples were taken from paddy fields located in the valley. Soil augers and chisels were used in sampling the soil. Systematic, random and composite sampling methods were used (Walsh and
Beaton, 1973). Grids of $60 \mathrm{~m}$ by $60 \mathrm{~m}$ were made from lateral 10 to lateral 21 then from lateral 6-8 in Zone A. In Zone B, random grids were sometimes used because some of the plots are not easily accessible. Each lateral has about 15 plots (see Fig. 2).

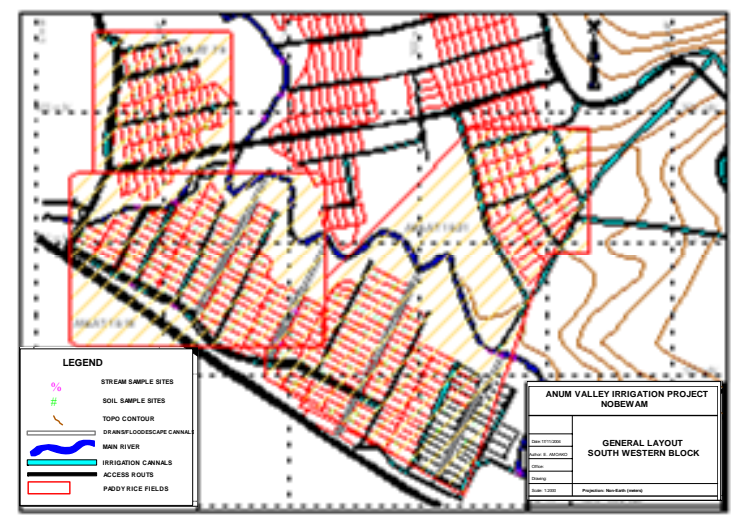

Fig 2 Soil Sampling Sites

Soil samples were taken at a depth of between 0 and $0.15 \mathrm{~m}$. Sample points were selected with the help of a site plan. A global positioning system (GPS) was also used to locate the sampling site. For convenience purposes, the over 150 sample sites were categorized into five blocks; AALAT79, AALAT10-15, AALAT16-21 in Zone A; (Fig 2) ABLAT1-5 and ABLAT6-8 in zone B; ABLAT1-5 and ABLAT6-8 not shown on the map are to the east of ABLAT16-21). Samples of each block were composited for analyses.

About $50 \mathrm{~g}$ each of the soil samples was mixed with $50 \mathrm{ml}$ of distilled water and stirred for an hour and the $\mathrm{pH}$ of the slurry measured. The soil samples were air-dried, ground and passed through a $2 \mathrm{~mm}$ mesh seive. About $10 \mathrm{~g}$ each of the samples was digested in $50 \mathrm{ml}$ of $0.05 \mathrm{M}$ EDTA for two hours. The samples were then filtered into a $100 \mathrm{ml}$ flask and topped to the mark with distilled water. Metal ion concentration was determined by atomic absorption spectrophotometry.

\subsubsection{Rice}

Two varieties of rice plants were sampled namely: BKE and WAS161B-9-FKR from areas where soil analytical results showed high levels of iron, lead, manganese and copper. The samples were washed thoroughly with distilled water. Each variety was cut into three parts; the roots (R), lower leaves (LL) and upper leaves (UL) and oven-dried at a temperature of $105^{\circ} \mathrm{C}$ for 36 hours. The samples were then pulverised and about $10 \mathrm{~g}$ each was digested in $30 \mathrm{ml}$ concentrated $\mathrm{HNO}_{3}$ for $30 \mathrm{~min}$ - 
utes. The slurry was diluted and filtered into a 100 $\mathrm{ml}$ volumetric flask and made to the mark with distilled water. The plant and soil filtrates were analysed using the Atomic Absorption Spectrometer (AAS) for iron, lead, manganese and copper.

\section{Results and Discussions}

The results of $\mathrm{pH}$ analysis for the soil samples as summarised in Table 1 revealed that the $\mathrm{pH}$ of the soils in the various zones was between 3.0 and 6.0. It can be inferred from these results that the soil is weakly acidic to moderately acidic.

Table 1 Results of $\mathrm{pH}$ and Available Heavy Metal Measurement

\begin{tabular}{|c|c|c|c|c|c|}
\hline Block & $\mathbf{p H}$ & $\begin{array}{c}\mathrm{Fe} \\
(\mathrm{mg} / \mathrm{kg})\end{array}$ & $\begin{array}{c}\text { Pb } \\
(\mathrm{mg} / \mathrm{kg})\end{array}$ & $\begin{array}{c}\text { Mn } \\
(\mathbf{m g} / \mathbf{k g})\end{array}$ & $\begin{array}{c}\mathrm{Cu} \\
(\mathrm{mg} / \mathrm{kg})\end{array}$ \\
\hline ABLAT 1-5 & 3.57 & 3326.4 & 4.8 & 86.4 & 3.9 \\
\hline ABLAT 6-8 & 4.22 & 4267.2 & 4.8 & 172.7 & 3.8 \\
\hline AALAT7-9 & 4.41 & 1686.6 & 4.8 & 16.3 & 3.4 \\
\hline AALAT10 - 15 & 4.01 & 1270.4 & 38 & 175.8 & 1.9 \\
\hline AALAT16-21 & 5.60 & 1462.8 & 48 & 66.7 & 1.0 \\
\hline
\end{tabular}

The available iron concentrations in the soils are presented in Table 1. The results revealed significant high concentrations of iron in the field. For example, more iron mobilisation was found around ABLAT1-5 (3 $266.4 \mathrm{mg} / \mathrm{kg}$ ) increasing to ABLAT6-8 (4 $267.2 \mathrm{mg} / \mathrm{kg}$ ), decreasing through ABLAT6-8 (3 $266.4 \mathrm{mg} / \mathrm{kg}$ ), AALAT16-21 (2 822.2 $\mathrm{mg} / \mathrm{kg}$ ) and AALAT7-9 (1 $686.6 \mathrm{mg} / \mathrm{kg}$ ) to AALAT10-15 (1 $270.4 \mathrm{mg} / \mathrm{kg})$ then increasing again in AALAT16-21 (1 $462.8 \mathrm{mg} / \mathrm{kg})$. The iron content seems to be influenced by $\mathrm{pH}$. The lower the $\mathrm{pH}$ the higher the iron content.

The high iron concentrations may be traced to the geological structure of the study area. Since the area is in a valley the soil can be described as siltyclay. This type of soils is known to contain high iron levels. It has been established by Mengel and Kirkby (1982) that under anaerobic conditions Fe (III) is reduced to $\mathrm{Fe}$ (II):

$\mathrm{Fe}(\mathrm{OH})_{3}+\mathrm{e}^{-}+3 \mathrm{H}^{+} \rightarrow \mathrm{Fe}^{2+}+3 \mathrm{H}_{2} \mathrm{O}$

According to the authors, this process of reduction is very important in the soil because plants are only able to absorb Fe in Fe (II) state. This process is enhanced in paddy soils, which are normally water logged, thereby creating anaerobic condition. High iron levels however produce toxic effects in rice plants known as 'bronzing'. Bronzing normally occurs in rice leaves containing more than $300 \mathrm{mg} / \mathrm{kg}$ of iron. The iron values were above this limit in the rice leaves $(400-506 \mathrm{mg}$ / $\mathrm{kg}$ ). Hence, this phenomenon was observed in some rice plants in the field during sampling. This phenomenon results in low crop yield. M;1

The type of tissue also influences the iron levels in the rice varieties (see Fig. 3). For example, the levels of iron in the roots and lower leaves of the two rice varieties were low in the roots and lower leaves but high in the upper leaves. This observation can be explained as follows: Fe is very important for plants because it serves as a catalyst for the synthesis of chlorophyll and oxidation-reduction in respiration (Allaway, 1968) hence the concentration of Fe in the upper leaves.

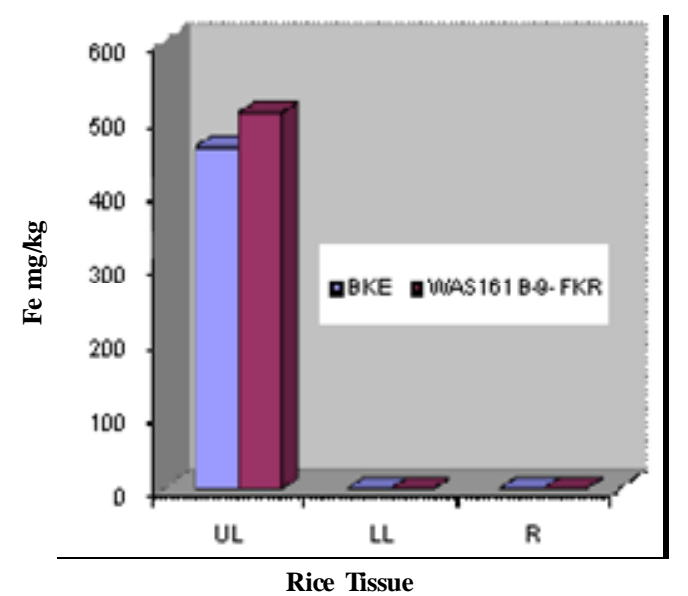

Fig 3 Level of Iron in the Rice Varieties

\subsection{Available Lead}

The soil analysis revealed that lead concentration is between $4 \mathrm{mg} / \mathrm{kg}$ and $49 \mathrm{mg} / \mathrm{kg}$. The highest values were found in a section of AALAT10-16 $(48.4 \mathrm{mg} / \mathrm{kg})$ and AALAT17-21 (37.6 mg/kg. These areas are very close to the Accra - Kumasi highway. The level of lead in the rest of the blocks was between $4.0 \mathrm{mg} / \mathrm{kg}$ and $5 \mathrm{mg} / \mathrm{kg}$.

The rice varieties around these areas of high lead concentration (above $30 \mathrm{mg} / \mathrm{kg}$ ) showed some levels of lead in the various rice tissues. The levels of lead vary between $7 \mathrm{mg} / \mathrm{kg}$ and $13 \mathrm{mg} / \mathrm{kg}$, in the upper leaves, $2 \mathrm{mg} / \mathrm{kg}$ and $7 \mathrm{mg} / \mathrm{kg}$ for the lower leaves and $3 \mathrm{mg} / \mathrm{kg}$ and $5 \mathrm{mg} / \mathrm{kg}$ for the roots (see Fig. 4).

The high levels of lead in a section of the Anum valley is most probably from exhaust of vehicles because the valley is adjacent to the Accra-Kumasi highway. According to Purves (1985), a major source of lead contamination of soils is atmospheric pollution from automobile exhausts. It can be inferred from the analysis that foliage and other plant produce from this valley and along the $\mathrm{Ku}-$ masi highway can be toxic to animals. Hence lead, 
which is toxic, can enter the food chain.

\subsection{Available Manganese}

The results of manganese $(\mathrm{Mn})$ analysis of the soils (see Table 1) showed high levels in some parts of Zones A and B. Values were high in ABLAT1-5 (1 $72.7 \mathrm{mg} / \mathrm{kg}$ ), AALAT10-15 (1 75.8 $\mathrm{mg} / \mathrm{kg})$ and AALAT16-21 (86.4 mg/kg) and followed by AALAT16-21 (66.7 $\mathrm{mg} / \mathrm{kg})$ and very low in ABLAT6-8 (16.3 mg/kg).

The level of $\mathrm{Mn}$ in the rice plant depends on the variety. The Mn level in the BKE is lower than the other variety (see Fig 5). The concentration in the roots is between $9.0 \mathrm{mg} / \mathrm{kg}$ and $112 \mathrm{mg} / \mathrm{kg}$ while that of the LL is in the range 6 to $162 \mathrm{mg} / \mathrm{kg}$ and $\mathrm{UL}$ is 80 to $134 \mathrm{mg} / \mathrm{kg}$.

Even though the soils and plant of Anum valley revealed relatively high levels of $\mathrm{Mn}$ the levels were within permissible limits of Food and Agricultural Organisation (FAO) for soil (5 $000 \mathrm{mg} / \mathrm{kg})$ and plant $(2500 \mathrm{mg} / \mathrm{kg})$ analysis.

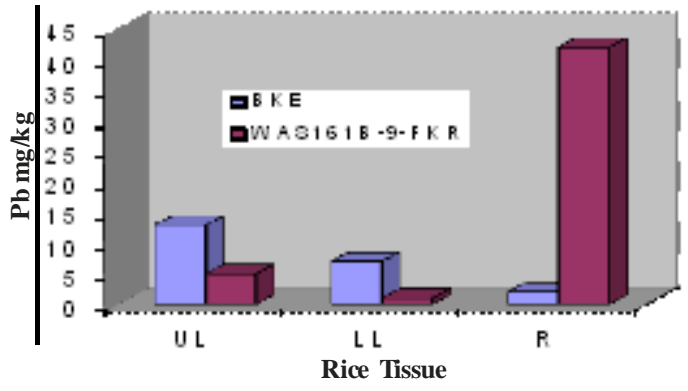

Fig. 4 Level of Lead in the Rice Varieties

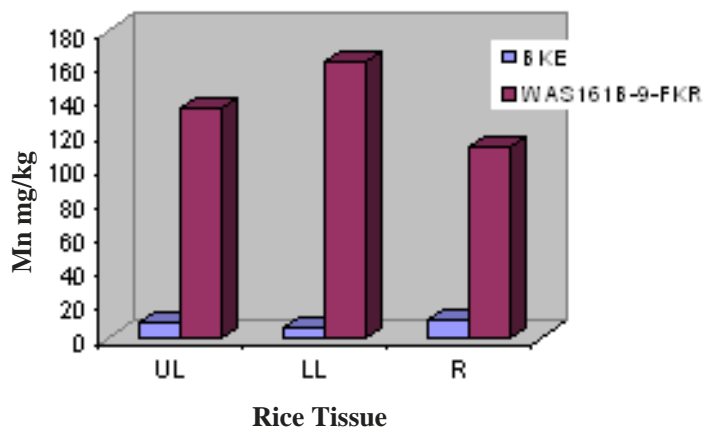

Fig. 5 Level of Manganese in the Rice Varieties

\subsection{Available Copper}

The levels of copper in the soil at various sites were as follows: ABLAT1-5 $(3.8 \mathrm{mg} / \mathrm{kg})$ and ABLAT6-8 (3.9 mg/kg), AALAT 7-9 (3.4 mg/kg) and AALAT10-15 (1.9 mg/kg) and decreasing in AALAT16-21 $(0.9 \mathrm{mg} / \mathrm{kg})$ (see Table 1$)$. The concentration of copper in plant was between $1.0 \mathrm{mg} /$ $\mathrm{kg}$ and $8 \mathrm{mg} / \mathrm{kg}$ (see Fig. 6). This falls within the normal range of 2 to $20 \mathrm{mg} / \mathrm{kg}$ as proposed by FAO. The rice varieties showed similar distribution of $\mathrm{Cu}(7 \mathrm{mg} / \mathrm{kg}$ and $8 \mathrm{mg} / \mathrm{kg})$ in the root tissues. However, the level in UL and LL for the $\mathrm{BKE}$ are lower than the other varieties.

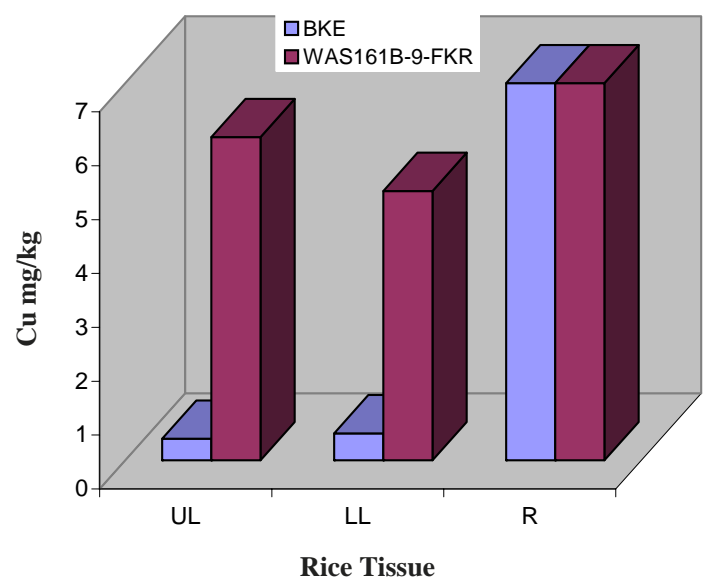

Fig. 6 The level of Copper Rice Plants

Rusell (1967) reported that the uptake of $\mathrm{Cu}$ by plants is related to the levels of available $\mathrm{Cu}$ in the soil. In the soil $\mathrm{pH}(3-7)$ the solubility of copper will normally be high hence the higher distribution observed in the plant tissues.

It can therefore be inferred from the results that accumulation of heavy metals is occurring in the inland valley of Anum, which is contributing to reduction of rice yield. The rice plant is also concentrating these heavy metals in various tissues hence the potential exists to produce contaminated food items. Consequently, the inland valleys can be environmental liabilities and sources of social conflict particularly when they fringe mineral concessions. Hence development of a mine in such areas should require a comprehensive Environmental Impact Assessment to ascertain the environmental quality of the adjoining inland valleys to offset any future social conflicts with the host communities.

\section{Conclusions}

The soils in Anum Valley are found to be weakly to moderately acidic hence crops that are sensitive to acid conditions cannot thrive well in the valley. Heavy metals like iron, lead, manganese and copper are present in the soil water. Lead is probably introduced into the field through vehicular exhaust emissions from the nearby highway.

Crops grown in inland valleys can take in heavy metals, which are concentrated in various tissues of the crop. Hence such fields can produce contaminated foods. Consequently produce from inland valleys should be closely monitored. Heavy metal intake together with low $\mathrm{pH}$ can lower crop 
yield as well.

Inland valleys can be environmental liabilities since biochemical reactions in such soils result in uptake of toxic heavy metal by crops which reduces the yield. Inland valleys can be sources of social conflicts if located in and around mining concessions or similar land use practices.

\section{References}

Anon. (1991), Comptran Engineering and planning Associates, $56 \mathrm{pp}$.

Allaway, W. H. (1978), Agronomic Controls over the Environmental Cycling of

Trace Elements. In Brady, N.C., (ed) The Nature and Properties of Soils. New York, Academic Press, pp. 235 -274.

Baker, A. J. M. and Brooks R. R. (1989), “Terres trial higher plants which hyperaccumulate metallic elements - A review of their distri bution, ecology and phytochemistry", Biore covery 1, pp. 81- 126.

Mengel, K., and Kirkby, E.A. (1982), Principles of Plant Nutrition. Publ International Pot ash Institute. Bern, Switzerland, pp. 473 515.

Purves, D. (1985), Trace Element Contamination of the Environment. Elsevier Science, New York, 243 pp.

Rusell, E.W. (1967), "Soil conditions and Plant Growth", Principle of Plant Nutrition. In

Mengel K., et. Al., (eds) International Potash Insti tute Bern. Switzerland, pp. 473- 514.

Walsh, L. M., and Beaton, J. D. (1973), Soil Test ing and Plant Analysis, Soil science Society of America, Madison, pp. 53 - 58.

Windmeijer, P. N. and Andriesse, W. (1993), Inland Valleys in West Africa: An Agroecological Characterization of RiceGrowing Environments in West Africa. Technical Report 3. DLO. Win and Staring centre, Wageningen. The Netherlands. Vol ume 2, 105 pp.

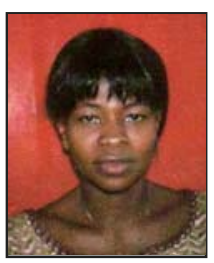

E. Buaben holds a BSc and MSc degrees from the Kwame Nkrumah University of Science and Technology (KNUST). She is currently working with the Anglican Diocesan Development and Relief Organisation as Gender Programme Officer.

\section{Authors}

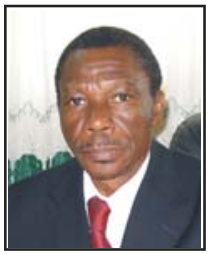

E. K. Asiam is an Associate Professor of Mineral Engineering. He holds a BSc and $\mathrm{PhD}$ degrees from the Kwame Nkrumah $\mathrm{h}$ University of science and Technology (KNUST), Kumasi. He lectures in Heap Leaching Technology, Alluvial mining, Hydrometallurgical Applications, Metallurgical Plant design and Operations, and Environmental Management and Safety. He has researched and consulted extensively on processing of refractory gold ores and environmental quality assessment and management. 